\title{
Rendőri vezető visszaemlékezései
}

\section{BALOGH János ${ }^{1}$}

\begin{abstract}
A cím kötelez. Írásomban - mint rendőri vezetői visszaemlékezés - három gondolatkört tartottam fontosnak kiemelni. Megosztom emlékeimet a rendörré válásomról, az akkor végzett tanulmányaim meghatározó pillanatairól. Visszaemlékezem első parancsnoki munkámra, amelyre nagyon fiatalon, 24 évesen kaptam lehetöséget, és a mai napig szívesen gondolok akkori beosztottjaimra, akik jóval idősebbek voltak nálam, mégis csapatként tudtunk jól együtt dolgozni. Személyes emlékeim felidézése során kiemelten fontosnak tartom azt az időszakot, amikor egy képzés sikeres elvégzését követően "váltottam" a korábbi munkámhoz képest, azon az áron is, hogy ez akkor alacsonyabb munkakörnek, visszalépésnek tűnt - azonban az élet azt igazolta, hogy időnként a tanulás, a fejlődés és a későbbi előmeneteli lehetőség érdekében lehet és kell is oldalra lépnünk. Vallom azt, hogy egész életünk egy nagy tanulási folyamat, amelynek során a jóból és a rosszból egyaránt le kell szürni a megfelelö tapasztalatokat, amelyek elöre vihetnek bennünket.
\end{abstract}

Kulcsszavak: rendőrré válás, tanulmányok, vezetői tapasztalatok, élethosszig tartó tanulás

\section{Hogyan lettem rendőr?}

A Kossuth Lajos Katonai Főiskolán szereztem diplomát, de jövőmet a Vám- és Pénzügyőrségnél képzeltem el. Már folyt a felvételi eljárás, és vártak a leendő munkahelyemen, amikor egy véletlen találkozás édesapám régi barátjával - aki akkor nyomozó volt Sopronban - új irányt szabott életemnek; a rendőrséget választom. Így kerültem próbaidős törzszászlósként a Soproni Rendőrkapitányságra nyomozó munkakörbe. A próbaidő leteltét követően alhadnagy lettem, majd megkezdtem a Rendőrtiszti Főiskola levelező tagozatán, bűnügyi szakon tanulmányaimat. (Akkor ez kétéves másoddiplomás képzés volt a felsőfokú végzettséggel rendelkezők részére.)

Meghatározó élmény volt számomra az ott eltöltött idő, nagyon sokat jelentett. A másoddiplomás képzés során gyakorlatilag ugyanazt oktatták nekünk a főiskolai tanárok, mint a nappali tagozatosoknak - nyilván olyan járulékos elemek elhagyásával, amit mi már diplomásként az egyéb tanulmányaink során megkaptunk. Rendszerbe foglalt ismereteket szerezhettünk, amelyek életre szólóan megalapozták tudásunkat. Sok kiváló tanárom volt, köztük olyan emblematikus személyek, mint Németh Zsolt vagy Blaskó Béla. Utóbbinál kétszer is államvizsgáztam, mert az első

\footnotetext{
Dr. Balogh János r. altábornagy, Országos Rendőr-főkapitányság, rendőrségi főtanácsos, országos rendőrfőkapitány. János Balogh, PhD, Police Lieutenant General, National Police Headquarters, Police Chief Counsellor, Chief Constable, Head of the National Police Headquarters.
} 
megmérettetésem eredményével nem voltam elégedett és javítóvizsgára jelentkeztem. Az éppen végzős nappalis hallgatóknak szervezett vizsgán újra Blaskó tanár úrral „kerültem szembe”, de már jóval felkészültebben, így aztán a siker sem maradt el. Amikor évekkel később a jogi egyetemet végeztem, szinte csak a különös rész időközben megváltozott szabályait kellett átolvasnom, mert az „ertéefes” tudásom tökéletesen elég volt.

A főiskola elvégzését követően lettem - kiváló tanulmányi eredményem miatt - soron kívül főhadnagy. Ekkor már közrendvédelmi szakterületen dolgoztam, hároméves bűnügyi gyakorlat után váltottam.

\section{Első vezetői tapasztalataim}

Első rendőri vezetői tapasztalataimat körzeti megbízotti alosztályon szereztem. 24 évesen én voltam az alosztály legfiatalabb tagja, a helyettesem majdnem kétszer annyi, de a beosztottak többsége is jóval idősebb, 40 fölötti volt. A katonai főiskola sok hasznos vezetői ismerettel készített fel, ennek köszönhetően a beosztott-vezető viszony nem volt teljesen ismeretlen számomra, de sokat segített a támogató környezet, amelybe kerültem. Én megadtam a tiszteletet a kornak, és megkaptam a tiszteletet a beosztásnak. Súlyos konfliktusom a beosztottakkal sosem volt. Nagyon jó csapat alakult ki, ahol például halászlé főzésekor sem felejtettük el, hogy ki kicsoda, de nem is kellett senkinek engedélyt kérni arra, hogy tehet-e Erős Pistát a levesbe. Akkoriban gyakran, hetente akár többször is összejöttünk munkaidő után, beszélgettünk, jó volt együtt lenni.

Hiszem, hogy mindenkitől és minden helyzetből lehet tanulni, e tekintetben nincs elvesztegetett idő. Voltak persze hangsúlyosabb, emlékezetesebb munkatársak, akiktől az átlagnál több mesterfogást „lestem el” vagy jobban befolyásolták fejlődésemet, de a lehető legtöbb emberre igyekeztem figyelni. Talán épp ennek köszönhető, hogy képes vagyok egy problémát több szemszögből vizsgálni, átgondolni, nem csak azt a megoldást keresni, ami kézenfekvő.

Az elmúlt évtizedekben több nagyra becsült vezetőm volt, akiktől sokat tanulhattam, mindegyikre hálával és tisztelettel gondolok. De soha, egyetlen pillanatra sem fordult meg a fejemben, hogy bármelyikre is hasonlítanom, vagy bármelyiket is másolnom kellene. Az én rendőri személyiségem sok rendőrtől ellesett jó vagy rossz példák nyomán, de alapvetően saját értékrenden nyugszik. Nem tudok elképzelni egy sablont, amelynek a helyébe illeszthetném magam.

\section{Egy életen át tanulunk}

Sopronból annak idején alapképzésre jelentkeztem Budapestre, a Rendőrség Különleges Szolgálatához (RKSZ), azzal a szándékkal, hogy ott helyben, a kapitányságon 
hozunk majd létre egy beavatkozó alosztályt vagy csoportot, és én szerettem volna komoly, rendszerszemléletű tudás birtokában szervezni ezt, nem pedig filmekből ellesett mozdulatokat alkalmazni...

Hat hónapos alapképzésen vettem részt. Ma is nagyon jó szívvel gondolok a kiképző parancsnokomra, bár akkor nem mindig éreztem így. Nagyon keményen fogott bennünket, sokat kellett edzeni, tanulni, a végletekig elfárasztott, de megérte!

Ott, az alapképzésen én voltam egyedül tiszt a 11 fős csoportban, de fél évig nem volt rendfokozatunk, csak a vezetéknevünkön szólítottak bennünket. Nem volt semmilyen kiváltságom azért, mert tiszt voltam: első naptól kezdve én is takarítottam a körletet. Lepusztult szekrényajtókat és bútorokat eszkábáltunk, mert egy rossz állapotú épületrészben kaptunk csak helyet. Szürke gyakorlóban és surranóban csináltuk végig a hat hónapot. Számos olyan dolgot éltem át, szenvedve vagy élvezettel, amit a legtöbb ember csak a filmekben lát. Testben, lélekben sokat erősödtem. Amikor együtt kínlódunk, cipeljük egymást hidegben-melegben, hegyen-völgyön - bizony másfajta szocializáció, mint amit megszoktunk.

A képzés befejezése után szólítottak meg, hogy ha van kedvem, maradjak a Különleges Szolgálatnál. Érdekes helyzet volt, mert akkor csak egy „irodaközeli” beosztás volt szabad, amit felajánlottak nekem. Megtisztelve éreztem magam és elfogadtam, bár ez valamelyest visszalépést jelentett számomra a korábbi munkakörömhöz képest. Közben beugrókat kerestek az ügyeletre, amelyhez nem igazán fúlt a foga senkinek, inkább „harcolni” akartak.

Én azonban jelentkeztem, mert úgy gondoltam, hogy még fiatal vagyok, ott a szolgálatnál kezdő is, így sokat tanulhatok, megismerhetek mindenkit, jobban átlátom majd a szervezet helyét, szerepét, tevékenységét. Ezért a vállalásért nagyon hálás volt az akkori parancsnok, és cserébe egy dolgot kérhettem tőle, és kértem is: azt, hogy szabadidőmben mehessek a bevetésekre, hogy tanuljak. Sokan néztek furcsán rám csakúgy, mint akkor, amikor annak idején a büntetőjogból javítani akartam, de ennek köszönhetően több bevetésen vehettem részt, mint azok, akiknek ez volt a fő feladata. Először persze csak ültem az autóban, és néztem, hogy mit csinálnak, majd egyre komolyabb részfeladatokat is kaptam. Később már egy bevetési alosztály vezetője, utána öt évig múveletirányító voltam, ami nagyon izgalmas dolog volt: előkészíteni a feladatokat, levezényelni és dokumentálni. Nagyon büszke vagyok arra, hogy rendkívüli esemény egyetlen általam vezetett bevetésen sem volt. Igyekeztem úgy csinálni, hogy csak az elvégzendő feladatra koncentráljunk, közben minél kevesebb sérelmet okozzunk.

Úgy gondolom, hogy a pályám során minden munkakörben voltak nehézségek, csalódások, konfliktusok, de minden területnek megvoltak a maga szépségei is. És megvolt a döntés (persze nem végtelen) szabadsága akkor is, amikor nagyon szúk volt a mozgástér. Az ókori görögök mondták, hogy két dolgon nem érdemes keseregni: amin tudsz változtatni, és amin nem.

Szerintem nem szabad úgy kezelni a problémákat, hogy csak essünk túl rajta, és feledjük el. Legyünk valóban túl a lehető legkisebb kárral, de tartsuk kézben és tanuljunk 
belőle azért, hogy még egyszer ilyenbe ne kerüljünk, vagy legalább már határozottabb, céltudatosabb emberként. Nem szabad behunyni a szemünket és várni, hogy „elmenjen mellettünk” a gond, mert akkor legközelebb is csak ezt tudjuk tenni. Mindig lesznek kihívások és problémák, amelyeket meg kell oldani. Ha megoldani nem tudjuk, akkor legalább éljük túl; de a túlélés sem begubózás. Szükséges hozzá ügyesség, aktivitás, amihez képességek, képzettségek, tapasztalatok kellenek. Elszántság kell, akaraterő, amelyet nem lehet csak a vészhelyzetben megszerezni. Apránként, folyamatosan kell fejleszteni magunkat, ahogy az élet nyújtja.

Nincs tehát menthetetlenül elvesztegetett idő. Akkor lesz azzá, ha hagyjuk, hogy az legyen.

Budapest, 2021. március 31.

\section{ABSTRACT}

\section{Memoirs of a Police Chief}

János BALOGH

The title obliges the author, and thus, in my paper-meant to present the memories of a police chief - I thought it important to highlight three areas of reflection. I share my memories of becoming a police officer and the defining moments of my studies at the time. I look back on my first job as a commander, which I was given the opportunity to have at a very young age, 24, and to this day I think fondly of my colleagues at that time, who were much older than I was, still, we were able to work well together as a team.

In recalling my personal memories, I consider extremely important the time when, after successfully completing a training course, I 'switched' from my previous position to a lower job level. Despite the fact that at the time it seemed a step backwards, life has shown that sometimes we can and should step aside to make use of learning, development and future career opportunities. I believe that our whole life is a great learning process, with both good and bad lessons to be learnt, experiences that can move us forward.

Keywords: becoming a police officer, studies, leadership experience, lifelong learning 